\title{
Bilingual Effect on the focus and Attention of children under Eight
}

Faizah Salah Al-Hammadi

Department of English Language - College of Arts

King Faisal University-Saudi Arabia 



\section{Introduction:}

The first years of child's age are the most important years which have a major impact in shaping the future knowledge of children. Studies indicate that there is a strong relationship between the ability of child of paying attention and the nature of mental processes, especially his attempts to organize his thoughts and uncover errors encountering him (Change and Burns, 2005, p. 26)

Studies attempted to uncover the relationship between language and identifying things, paying attention to them and controlling thoughts and feelings in different situations. Scholars were divided into two main teams, the first team sees that there is a relationship between language development and enhancing cognitive development (Muller et al, 2004, p. 1590) and the second team reiterates that language is separate from attention and has no effect on enriching attention (Wang et al, 2004, p. 103). The follower of writings of educational scientists knows that studies carried out up till present did not conclusively resolve the cognitive characteristics of bilingual children (warburton et al, 1996, p. 171). Thus, the present study comes as an attempt of the researcher to enrich this field of studies to which we are in need day after day.

Importance of the study: 
(1) Attention is one of the most important cognitive processes with which scientists have been occupied and benefited at the same time; attention is to make better items or specific locations within a diverse and complex sensory environment which represents the foundation of human knowledge, as well as our ability to organize our response especially with conflicting situations (Holmpe and Jonson, 2005, p.1).

(2) Studies revealed that bilingual children have better cognitive characteristics than monolingual children (vrbanik et al, 2001, p. 13). In the same context, other studies deny the results of first studies so we need a lot of researches to focus on the impact of bilingualism on cognitive processes.

(3) The phenomenon of growing numbers of bilingual children has become a reality in the Arab society for many reasons related to the nature of child study, including reasons of residence for extended periods abroad or for reasons related to marriage of different nationalities with another language which necessitated the need to study this phenomenon extensively.

\section{Aim of the study:}

To identify the differences of bilingual and monolingual children related to attention and enhancing cognitive abilities. 


\section{Hypotheses of the study:}

- First Hypothesis: There are no statistically significant differences in attention among children of empirical research sample.

- Second Hypothesis: There are no statistically significant differences in attention among bilingual and monolingual children.

- Third Hypothesis: There are no statistically significant differences in executive attention among children in terms of gender variable (male/female).

- Fourth hypothesis: There are statistically significant differences in attention among bilingual children (in high concentration who study the second language for about 20 classes per week or more) as well as bilingual children (in medium to low concentration who study the second language for less than 3 classes per week).

\section{Terms of the Study:}

Attention: It is a focus on part of the information stored in the sensory memory (Abutalebi, 2007, p. 242).

\section{Definition of Posner :}

An organized and planned knowledge process of a high level in helping individuals neglect disjointed stimulants and pay more attention to meaningful stimulants. (Posner, 1990, p. 1915). 


\section{Bilingualism:}

\section{Definition of Webster's Dictionary 1992:}

The ability to use two languages fully or fluently (Cayene et al, 1992, p.96)

\section{Cognitive processes:}

Cognitive mental growth refers to changes in the individual's knowledge and his understanding and ability to think about surroundings. The processes that increase human knowledge are called cognitive processes including some processes like attention, perception, recollection and reflection (Mahendra and Trouard, 2003, p. 1227).

The reality of language: The reality of language consists in the fact that it is words put for certain meanings, any word (name) (Crosson and Benefield, 2003, p. 1061) associated with the mind in the specific sense of "named", a meaning with something specific imagined in mind and stored be in a file under the name known and can be remembered and retrieved later with all the qualities, characteristics and conditions of related data in the whole file contained in mind by mans of the name identity, the file name which is the identity of the thing (Stowe and Haverkort, 2005, p. 997) .

Linguistic fortune of children and its development:

It can be noted that through studies conducted by specialists in this area, that children at the age of three have a 
linguistic balance of about 900 words, and at the age of four years an estimated linguistic balance of 1500 words and at the age of six years an estimated of two thousand and five hundred words (Segalowitz and Hulstijn, 2005, p. 374-379), and since the means and methods used by researchers in the linguistic fortune balance the children were not on one form coefficients change in number of words which vary greatly in some of these ways prompts the child to express. The meaning of the words in his own language, while trying in some way to get the meaning of the word used in a paragraph or a sentence given by the child, and there are other ways to draw pictures and not to ask the child over to point to an image among many similar images (lee and Devlin et al, 2007, p. 1184-1189),

\section{Characteristics of children's language:}

1- Child language tends to hang with tactile, not abstract meanings because child first learns to speak out what his senses begins to fall upon as linguistic terminology called child selves names that are firstly recognized and then enunciates the words Dad, Mum, milk, loaf and then is gradually recognizing words like rabbit, cat, bed, chair (Price, 2000, p. 336),

\section{2- Child language is predominantly centered on}

himself. This is because the child before he enters school may not be socially but had overcome selfishness and love itself, perhaps because his presence at this stage within his family 
which gives all the love, affection and tenderness all reflect upon making him thinks only of himself (Lamm and Vitouch, 1999, p. 138).

3- Simple language which tends to lack precision and selection in question: Notable in this characteristic, that the dictionary of child grows gradually in the first years of age until to be about 2000 words and when he reaches the age of six years, and takes the primary school stage it increases, because he added new words(Coggins and Kennedy, 2004, p. 73).

\section{4- Children have some components and concepts of speech:}

Modern educational studies indicated that most high growth and language development of children, because the language development is a manifestation of mental development; affected by two factors: learning and maturity (Indefrey, 2006, p. $303)$.

As for children's concepts about things they come according to their experiences in life, and during these experiences the child must have attached between things, symbols, concepts which are few and limited, especially at the beginning of experience as these concepts increase expertise.

\section{Theories that explain bilingualism:}

First: The code-Switching Theory:

Both scientists Lambert and Peal (1962) developed a theory to explain bilingualism. Their theory assumes that 
children can switch from one language to another easily and they have the ability of automatic linking. They assumed that the ability to switch from one language to another can give children flexibility in mentality better than monolingual. Because experience in dealing with two languages need to be flexible in order to switch from one language to another, and this flexibility is reflected on child's thinking when solving tests.(Kroll $\& \boldsymbol{D e}$ Groot., 2005, p.187) Studies by Lambert and Bill (Lambert and Peal, 1962) gave an opposite opinion which reversed old results and managed to find a positive direction of bilingual effect; as scientists conducted extensive studies on children of the city of Montreal who use both languages English, French, and researchers followed new experimental methods and criticized old methods and the results of their studies have shown that bilingual children's cognitive features a clear verbal and nonverbal communication standards (Holff, 2005, p254).

\section{Second: Objectification Theory}

Vygotsky (1962) supposed that bilingualism gives children more flexibility in the naming of things, in other words, children realize the bilingual nature of the relationships between names and things as a normal relationship, they call the thing by different names, leading to enhancing the skill to distinguish between words and their meanings, and dual language can express one thought of using different languages and through a process of objectification that the children can call the concepts 
of high-level coding and renewal. Bilingualism tends to see the language system of a second language not just knowing only a second language but also leading to enhance knowledge in general and understanding of linguistic processes (Rosebery, 1987, p.173).

\section{Third hypothesis: The Verbal mediation hypothesis}

Luria (1961) and Vygotsky emphasized the importance of functional language, according to this theory, the language is thinking tool and using children in general language for the purpose of directing their thoughts and implementation of their actions through an understanding of the problem and planned consciously when children think of solving the problem of the language mediates the use of rules, rules is a set of mental representations that are on a formula (if - permission) and the function of language is to get the information and see the owners of this theory is that naming the contents of consciousness facilitates self-reflection - any - Child on the knowledge used by the process of reflection occurs conscious meditation as a result of the growth of capacity beyond cognitive. It also facilitates the process of separation or independence of the child from the surrounding environment, which called out the psychological independence, and contributes to processes of meditation and independence in the further growth of the mechanisms of cognitive control (Muller et al, 2004, p.1599).

Fourth, Analysis and Control Theory (1999) 
Bella Stoke found through their experiences on bilingual children that the control element is growing earlier in bilingual children when compared with monolingual language, and what was the control element enhanced when bilingual, the awareness beyond the language will be stronger awareness located at monolingual peers. (Bialystok, 1999, p. 146)

Several studies carried out by Bialystock and colleagues proved the superiority of bilingual children in tasks requiring an element of control, whereas Shapero and Bialystock (2005) held a comparison between children's performance as for monolingual and bilingual children were aged about 6 years, and is used researchers tests mysterious shapes, the researchers found that bilingual excel in distinguishing between the mysterious shapes that require them to see the shape in more than one side. (Bialystok, and Shapero, 2005, p. 595)

\section{Psychology of Language:}

Language is a psychological phenomenon, so there is interest in studying the mental aspects of language, speech and the role of language and its impact on memory and cognition, thinking, attention and learning. We can say that Psycholinguistics is the study of the psychological factors and neurobiological and their relationship to the mechanism of language acquisition and operations of mind associated with the understanding and production of language in terms of addressing the brain for language while transmitting and receiving and 
dealing with language diseases and conversational(Gaser and Schlaug, 2003, p. 9242), such as dyslexia and aphasia, forgetfulness and delayed speech and interpretation of the acquisition process language since childhood psychological configuration for learners of foreign language, also other psycholinguistics stated the applications of the most important contribution to the development of the content of language learning, taking into account the gradient of language in language acquisition(De bleser and Dupont, 2003, p. 443). For example, there are suffixes acquired by the child in accordance with the gradation in terms of difficulty and time as demonstrated by several studies including a study by Stephen (Indefrey, 2006, p. 281). Steven Krashen is also interested in psycholinguistics brain mechanisms and cognitive monolingual language contained prescriptive grammar with a harness biology and cognitive science and neuroscience and the theory of integration informational to learn how the brain processing of language. (Fabbro, 2001, p. 211).

Research methodology and procedures: The current research experimental approach adopted to achieve the goals of current research was to determine search and selection of a representative sample of him, and the preparation of standards is characterized by honesty and consistency, objectivity and the setup of the experiment, and then uses the appropriate statistical tools to analyze and manipulate the data statistically. 


\section{The sample description:}

It has been identified by study population in children of male less than 8 years and females who were divided into two groups monolingual group and the bilingual application was on children in a number of kindergartens and primary schools that receive bilingual children and other mono children's language was chosen as the number of 104 boys and girls to perform the application of them and the other part children are dealing only in Arabic dealing in Arabic and English, and when you perform tests managed 84 boys and girls just continue which is like $80 \%$, which is a very good percentage in this kind of research where this number will provide an analysis of the results statistically each variable enough the number of males in this test has reached 51 children and 33 female child.

It has been taken into account the diversity of sources that resulted in the acquisition of children's second language has gained as a result of accommodation to study abroad parents and others of nationality who speak English.

\section{Tools of the study:}

First: Resolution Most of the questionnaires available intentionally to question individuals about the number of languages used by the child and the type of language used by the people who deal with them the child. In the current research it 
has been relying on a questionnaire prepared by the American Speech and Language and Hearing Association.

American speech - Language - Hearing association (A.S.L.H) (ofan and Zohary, 2007, p. 1249-1259) Based on the following reasons: 1) Suitability for the age group for the current search

2) Being a modern, consistent with the theoretical definition of bilingualism.

Before proceeding to circulate the questionnaire, it was sent to a group of specialists to examine the test vocabulary and to ensure that the degree of suitability for the study was the move resulted in a modified three paragraphs in the form of drafting language and after review by arbitrators for the second time won the paragraphs of the test on the support and confirm the suitability degree $100 \%$ no complete agreement.

\section{Readiness to take the test:}

Before starting the children who have been the stability, they meet in order to be a sample study was to communicate with their parents through schools and nurseries, which belong to the management and taking divided on tests and get them some needed to study the information as the number of languages in which it handles the children and a means acquisition of language, and their assessment of the ability of their children the 
means to respond to and loved them more cooperative and responsive to them.

Calculation of the stability of test: To ascertain the credibility and stability of the test has been relying on the method of analysis of variance using equation (Kuder-Richardson20) (Bookheimer, 2002, p. 10-40).

As the stability of the test averaged $(0.87)$, which is high and longer acceptable in this kind of tests.

Second: Testing the working memory: For the purpose of rewarding experimental groups variable over the working memory was Zelazo and Fry in measuring the working memory for pre-school children.

1) Tool description: The tool consists of 10 cards containing one such card at a group of photos of things varied, the experimenter to tell the child that will affect my favorite things, and then the experimenter reference to a single image in the first card and the assistant researcher pronounces them with each new card adding single experimenter one to be up to the last card in which the experimenter indicates the (10) vocabulary.

2) Tool correction: Test score $=$ number of correct vocabulary that retrieved the baby with the arrangement in the retrieval is unnecessary, and ends the test when the child faulting retrieval on the two cards in a row. 
3) Concept Validity: The test will be honest when distinguishes between young children to adults and children, have been testing the application on sample of children consists of 30 boys and girls distributors in two groups the average age for the first sample (5.5) years while the average age for the second sample (7.5) years after the application of the test got younger on average my children (5.133) and a standard deviation of (1.552) while the arithmetic mean of the grades older children lived on the same test (6.266) and a standard deviation of (1.032) and after using the second test for two independent samples show that the second calculated value (3.354), a statistically significant at the level of (0.05) and the degree of freedom (28) reaching tabular value (2.048), suggesting that young adults excel on the test of memory and therefore honesty is achieved.

\section{** Exploratory sample application:}

For the purpose of know the clarity of the test instructions and the calculation of time and finding the difficulties that can be faced with the researcher during the job performance of the application of the test on a sample of 20 children by 10 males and 10 females, were turned out of the researcher after application to the test instructions and paragraphs clear while the time it takes between 5-3 minutes and an average of 4 minutes. 4) Persistence Reliability: Stability refers to how the homogeneity test the long-term results and that the more the test 
is more stable as the test gave us the same results when similar circumstances (French and Roth et al, 2005, p. 763-776).

\section{Test-retest method:}

The reliability coefficient calculation in this way based on previous studies, the scale was applied on 06.05.2016 on a sample of 30 children by 20 males and 10 females were then reapplication after three weeks later on 27/5 / 2016 and using the correlation coefficient (Pearson) to measure the relationship between grades in the two applications totaled reliability coefficient $(0.80)$ which is a high correlation coefficient compared with the results of previous studies, which took place on the age groups of similar studies. The application of test: There is a final agreement on the sample test store, which estimated the number of 84 boys and girls by 51 male and 33 female and they were rounded up in a dedicated training room is available with the necessary ingredients for testing and so on throughout the three weeks succession according to a timetable agreed with disabled children.

Study sample distribution by variable of type and level of study:

\begin{tabular}{|l|c|c|c|}
\hline \multicolumn{1}{|c|}{ Type } & KG & Primary & TOTAL \\
\hline Males & 32 & 19 & 51 \\
\hline Females & 17 & 16 & 33 \\
\hline Total & 49 & 35 & 84 \\
\hline
\end{tabular}


The following statistical methods were used to analyze the test results. (T-test) for two independent samples: has been used to calculate the differences between the younger group and the older children on a test over the working vocabulary of sensory memory, so as to extract the truth in a way differentiation of age.

Pearson correlation coefficient (Pearson Correlation) has been used to calculate stability in a way re-testing to test the working memory. Spearman equation - Brown has been used to correct the reliability coefficients.

Analysis of variance for the purpose of knowledge of parity between the experimental groups. Chi-square was used to calculate the differences between experimental groups. Results of the study: First hypothesis: There is no significant differences in the attention to experimental research sample after application of the test and use of statistical methods mentioned above the value calculated chi square is 22.32 and therefore it is greater than tabular value of 31.41 and accordingly the hypothesis was rejected whereas the results suggest the existence of significant differences, which confirms that children test shop to have the capacity that can be measured on attention.

Second hypothesis: There is no significant differences in attention to the children's differences in the language element (dual / mono) after the test on the selected sample, which was divided to two bilingual and numbered 42 and monolingual 42 children managed 33 children from bilingual children pass the 
test compared to the application 21 the number of boys and girls of monolingual children while failing to pass the test 9 children who are fluent in English and Arabic in exchange for the failure of 21 monolingual children and a baby. It came as the value of the calculated chi square to (9.82) higher than the tabular value of (5.43) at the level of (0.05) and were accordingly rejected the null hypothesis including confirms significant differences between bilingual and monolingual children.

Third hypothesis: There is no significant differences in attention to children of sample differences according to type variable after application of test a value calculated chi square to (0.76) which is less than tabular value of (4.21) at the level of (0.05) and accepted the null hypothesis and this confirms that male and female are equal in ability to pay attention and there is no difference between them can be emphasized that any kind is not a factor with an effect on attention.

Fourth hypothesis: There are statistically significant differences in attention among bilingual children (in high concentration who study the second language for about 20 classes per week or more) as well as bilingual children (in medium to low concentration who study the second language for less than 3 classes per week).

So as to test the validity of hypothesis, it has been applied to a number of 40 male and female children as the percentage of males reached $50 \%$ out of the sample whereas the percentage of 
females reached $50 \%$ in the form of 10 male and female children in international preschools and schools wherein English language is intensively taught as well as 10 male and female children in governmental schools wherein English language is taught for two classes per week.

The homogeneity of age between both groups has been taken into account so as to reach the highest degree of precision as the value of $F$ calculated rated less than the value of $F$ in table on the significance of $(0.05)$ which indicated the conformity of sample in terms of age. By reading the literature review as well as scientific references, the researcher designed a test for measuring the difference of attention degrees among bilingual children and those who study language in an intensive level as well as bilingual students who study language moderate to low level. The researcher briefed the test to some professors in psychology and applied linguistics as well as children education. They approved the test and confirmed its validity for measuring the differences in attention between both groups of the study.

\section{Description of the test: The test is consisting of five main pivots:}

Pivot one: The ability to distinguish between similar words as the researcher performed a review of 10 paragraphs in front of each child in this pivot. Each paragraph contains 3 words including two similar words that the child should distinguish between them. 
Pivot two: The ability to remember information as the researcher tested the remembrance degree and its difference between both groups with seven paragraphs to listen to conversations followed by a number of questions, arrangement of events in the conversation, recognize some chants by music and remembering previous lessons as well as narrating tales and finally asking about its main events.

Pivot three: The ability of improvisation as the researcher stated some events and left the chance for children to expect the end of event and as well it gave children a number of letters to form the largest possible number of words using such letters.

Pivot four: The ability to complete blank or missing parts and recognize lost things by reviewing names of groups known to the child or tales and chants; it was not including some phrases or names as well as deleting some of the names of his teachers.

Pivot five: The concentration and expressing feelings as the researcher replaced some letters with other words and asked the child to pronounce the new letters and to express himself in various situations and to express his feeling as well in certain cases determined for him.

Preparations for applying the test: Prior to applying the test, the internal integrity and consistency of test has been 
verified by means of calculating correlation coefficients between the degree of each of the pivots of attention as well as the total degree of test as follows:

\begin{tabular}{|l|c|l|}
\hline \multicolumn{1}{|c|}{ Pivot } & $\begin{array}{c}\text { Correlation with total } \\
\text { degree }\end{array}$ & \multicolumn{1}{|c|}{ Significance level } \\
\hline - $\begin{array}{l}\text { The ability to } \\
\text { distinguish between } \\
\text { similar words }\end{array}$ & 0.817 & Significant at 0.01 \\
\hline - $\begin{array}{l}\text { The ability to } \\
\text { remember information }\end{array}$ & 0.669 & Significant at 0.01 \\
\hline - $\begin{array}{l}\text { The ability of } \\
\text { improvisation }\end{array}$ & 0.901 & Significant at 0.01 \\
\hline - $\begin{array}{l}\text { The ability to complete } \\
\text { missing parts }\end{array}$ & 0.740 & Significant at 0.01 \\
\hline $\begin{array}{l}\text { The ability to } \\
\text { concentrate } \\
\text { express feelings and }\end{array}$ & 0.841 & Significant at 0.01 \\
\hline
\end{tabular}

In view of the above, it is clear that all correlation coefficients between the preceding pivots and the total degree of scale significant at $(0.01)$ level which indicates that internal consistency of scale is integral after applying the test and the results were as follows:

\begin{tabular}{|l|l|l|l|l|l|}
\hline Factor & Group & Gender & $\begin{array}{l}\text { Chi } \\
\text { square } \\
\text { total }\end{array}$ & $\mathbf{R}$ & Significance \\
\hline \multirow{2}{*}{ Attention } & $\begin{array}{l}\text { Bilingual } \\
\text { intensively }\end{array}$ & $\begin{array}{l}\text { Males } \\
\text { and } \\
\text { females }\end{array}$ & 8.5 & 0.74 & Significant at 0.01 \\
\cline { 2 - 6 } & $\begin{array}{l}\text { Bilingual } \\
\text { moderately }\end{array}$ & $\begin{array}{l}\text { Males } \\
\text { and } \\
\text { females }\end{array}$ & 14.5 & 0.92 & Significant at 0.01 \\
\hline
\end{tabular}


Reviewing the above table, the researcher revealed that there is a significant relation between the degrees of bilingual children intensively and bilingual children moderately according to the scale of attention in favor of intensive bilingual children.

Conclusion: The study revealed that there are high rates of attention among bilingual children compared to their monolingual peers; the rate of attention also increased among children who study language intensively more than those who study it moderately. The researcher observed that there are many interconnected factors which consist in the increase of knowledge of those

children in comparison with their peers including:

- The ever-increasing interest given to bilingual child from his school and teacher in international schools and the quality of dealing with him compared to his monolingual peers and the nature of schools in which they study.

- The researcher noticed that fathers and mothers of bilingual children are keen on providing good atmosphere of communication and listening to their children compared to monolingual children that may be adversely affecting their knowledge development and awareness.

- The results of tests reflected the important role played by instructors of international $\mathrm{KG}$ and primary schools in 
applying classroom activities related to language and developing its skills to be used in different fields of life.

\section{Recommendations:}

- Educators and people in charge of education should pay more interest to diffuse the culture of bilingualism of language and encourage parents to teach their children more than one language.

- Encouraging carrying out many studies aiming to develop cognitive skills of children as well as follow up its development throughout different stages of education.

- The necessity of qualifying female teachers who deal with children of this important age group to be qualified properly as they are concerned with shaping the knowledge and cognitive skills of children in such early stage especially in dealing with multilingual children.

\section{References}

Abutalebi, J., \& Green, D. (2007). Bilingual language production: The neurocognition of language representation and control. Journal of Neurolinguistics, 20, 242-275.

Balaguer, R. D., Sebasti' an-Gall'es, N., Diaz, B., \& Rodriguez-Fornells, A. (2005). Morphological processing in early bilinguals: An ERP study of regular and irregular verb processing. Cognitive Brain Research, 25, 312 Birdsong, D. (2006). Age and second language acquisition and processing: A selective overview. In M. Gullberg and P. Indefrey (Eds.), The cognitive 
neuroscience of second language acquisition (pp. 9-49). Malden, MA:

Blackwell.

Bookheimer, S. (2002). Functional MRI of language: New approaches to understanding the cortical organization of semantic processing. Annual Review of Neuroscience, 25, 151-188.

Briellmann, R. S., Saling, M. M., Connell, A. B., Waites, A. B., Abbott, D. F., \& Jackson, G. D. (2004). A high-field functional MRI study of quadrilingual subjects. Brain and Language, 89, 531-542.

Calabrese, P., Neufeld, H., Falk, A., Markowitsch, H. J., Muller, C., Heuser, L., et al. 2001). Word generation in bilinguals: fMRI study with(implications for language and memory processes. Fortschritte der Neurologie Psychiatrie, 69, 42-49.

Chee, M. W. L., Caplan, D., Soon, C. S., Sriram, N., Tan, E. W. L., Thiel, T., et al. (1999). Processing of visually presented sentences in Mandarin and English studied with fMRI. Neuron, 23, 127-137.

Chee, M. W. L., Hon, N., Lee, H. L., \& Soon, C. S. (2001). Relative language proficiency modulates BOLD signal change when bilinguals perform semantic judgments. NeuroImage, 13, 1155-1163.

Chee, M. W. L., Weekes, B., Lee, K. M., Soon, C. S., Schreiber, A., Hoon, J. J., et al. (2000). Overlap and dissociation of semantic processing of Chinese characters, English words, and pictures: Evidence from fMRI. NeuroImage, 12, 392.

Coggins, P. E., Kennedy, T. J., \& Armstrong, T. A. (2004). Bilingual corpus callosum variability. Brain and Language, 89 .

Colombo, J. (1982). The critical period concept: Research, methodology, and theoretical issues. Psychological Bulletin, 91.

Crosson, B., Benefield, H., Cato, M. A., Sadek, J. R., Moore, A. B., Wierenga, C. E., et al. (2003). Left and right basal ganglia and frontal activity during language generation: Contributions to lexical, semantic, and 
phonological Journal of the International Neuropsychological Society, 9 , 1061-1077.

De Bleser, R., Dupont, P., Postler, JD., Mortelmans, L., et al. (2003). The organisation of the bilingual lexicon: A PET study. Journal of Neurolinguistics, 16, 439-456.

De Bot, K. (2008). The imaging of what in the multilingual mind? Second Language Research, 24, 111-133.

Dehaene, S., Dupoux, E., Mehler, J., Cohen, L., Paulesu, E., Perani, D., et al. (1997). Anatomical variability in the cortical representation of first and second language. NeuroReport, 8, 3809-3815.

Dufour, R., \& Kroll, J. F. (1995). Matching words to concepts in 2 languages: A test of the concept mediation model of bilingual representation. Memory and Cognition, 23, 166-180.

Eigsti, I. M., \& Schuh, J. M. (2008). Neurobiological underpinnings of language in Applied Linguistics.

Fabbro, F. (2001). The bilingual brain: Cerebral representation of languages. Brain and Langwage, 79, 211-222.

Francis, W. F. (2003). Discussion of colloquium panel on recent investigations of the bilingual brain. Presented at the 4th International Symposium on Bilingualism, Tempe, AZ.

Frenck-Mestre, C., Anton, J. L., Roth, M., Vaid, J., \& Viallet, F. (2005). Articulation in early and late bilinguals' two languages: Evidence from functional magnetic resonance imaging. NeuroReport, 16, 761-765.

Gaser, C., \& Schlaug, G. (2003). Brain structures differ between musicians and non-musicians. Journal of Neuroscience, 23, 9240-9245.

Golestani, N., Paus, T., \& Zatorre, R. J. (2002). Anatomical correlates of learning novel speech sounds. Neuron, 35, 997.

Green, D., Crinion, J., \& Price, C. (2006). Convergence, degeneracy and control. In M. The cognitive neuroscience of second language acquisition (pp. 99-125). 
Green, D. (2008). Bilingual aphasia: Adapted language networks and their control. Annual Review of Applied Linguistics, 28.

Grosjean, F. (1982). Life with two languages. An introduction to bilingualism. Cambridge, MA: Harvard University Press.

Grossman, M., Cooke, A., DeVita, C., Lee, C., Alsop, D., Detre, J., et al. (2003).

Grammatical and resource components of sentence processing in Parkinson's disease: An fMRI study. Neurology, 60, 775-781.

Hernandez, A. E., \& Meschyan, G. (2006). Executive function is necessary to enhance lexical processing in a less proficient L2: Evidence from fMRI during picture naming. Bilingualism: Language and Cognition, 9, 177-188. Indefrey, P. (2006). A meta-analysis of hemodynamic studies on first and second language processing: Which suggested differences can we trust and what do they mean? Language Learning, 56, 279-304.

Klein, D., Milner, B., Zatorre, R. J., Zhao, V., \& Nikelski, J. (1999).

Cerebral organization in bilinguals: A PET study of Chinese-English verb generation. NeuroReport, 10, 2841-2846.

Lamm, C., Bauer, H., Vitouch, O., \& Gstattner, R. (1999). Differences in the ability to process a visuo-spatial task are reflected in event-related slow cortical potentials of human subjects. Neuroscience Letters, 269, 137-140. Lee, H., Devlin, J. T., Shakeshaft, C., Stewart, L. H., Brennan, A., Glensman, J., et al. (2007). Anatomical traces of vocabulary acquisition in the adolescent brain. Journal of Neuroscience, 27, 1184-1189.

Mahendra, N., Plante, E., Magloire, J., Milman, L., \& Trouard, T. P. (2003). FMRI variability and the localization of languages in the bilingual brain. NeuroReport, 14, 1225-1228.

Marian, V., \& Spivey, M. (2003). Bilingual and monolingual processing of competing lexical items. Applied Psycholinguistics, 24, 173-193.

Mummery, C. J., Ashburner, J., Scott, S. K., \& Wise, R. J. S. (1999). Functional neuroimaging of speech perception in six normal and two 
aphasic subjects. Journal of the Acoustical Society of America, 106, 449.

Neubauer, A. C., Grabner, R. H., Freudenthaler, H. H., Beckmann, J. F., \& Guthke, H. (2004). Intelligence and individual differences in becoming neurally efficient. Acta Psychologica, 116, 55-74.

Neville, H., \& Bavelier, D. (2002). Human brain plasticity: Evidence from sensory deprivation and altered language experience. Plasticity in the Adult Brain: From Genes to Neurotherapy, 138, 177-188.

Ofan, R. H., \& Zohary, E. (2007). Visual cortex activation in bilingual blind individuals during use of native and second language. Cerebral Cortex, 17, 1249-1259.

Pallier, C., Dehaene, S., Poline, , A. M., Dupoux, E., et al. (2003). Brain imaging of language plasticity in adopted adults: Can a second language replace the first? Cerebral Cortex, 13, 155-161

Paradis, M. (1994). Neurolinguistic aspects of implicit and explicit memory: Implications for bilingualism and SLA. In Ellis N. (Ed.), Implicit and explicit language learning (pp. 393-419).

Paradis, M. (2004). A neurolinguistic theory of bilingualism. Amsterdam, J. Y., et al. (1988). Cerebral metabolic effects of a verbal fluency test: A PET scan study. Journal of Clinical and Experimental Neuropsychology, $10,565-575$.

Penfield, W., \& Roberts, L. (1959). Speech and brain mechanisms.

Princeton, NJ: Princeton University Press.

Perani, D., \& Abutalebi, J. (2005). The neural basis of first and second language processing. Current Opinion in Neurobiology, 15, 202-206.

Perani, D., Abutalebi, J., Paulesu, E., Brambati, S., Scifo, P., Cappa, S. F., et al. (2003). The role of age of acquisition and language usage in early, high-proficient bilinguals: An fMRI study during verbal fluency. Human Brain Mapping, 19, 170-182.

Perani, D., Dehaene, S, et al. (1996). Brain processing of native and foreign languages. NeuroReport, 7, 2439-2444. 
Perani, D., Paulesu, S., Bettinardi, V., et al. (1998). The bilingual brain:

Proficiency and age of acquisition of the second

language. Brain, 121, 1841-1852.

Price, C. J. (2000). The anatomy of language: Contributions from functional neuroimaging. Journal of Anatomy, 197, 335-359.

Pu, Y. L., Liu, H. L., Spinks, J. A., Mahankali, S., Xiong, J. H., Feng, C. M., et al. (2001). Cerebral hemodynamic response in Chinese (first) and English (second) language processing revealed by event-related functional MRI.

Magnetic Resonance Imaging, 19, 643-647.

Reiterer, S., Hemmelmann, C., Rappelsberger, P., \& Berger, M. L. (2005).

Characteristic functional networks in high- versus low-proficiency second language speakers detected also during native language processing: An explorative EEG coherence study in 6 frequency bands. Cognitive Brain Research, 25, 566-578.

Rodriguez-Fornells, A., Balaguer, R. D., \& Munte, T. F. (2006). Executive control in bilingual language processing. Language Learning, 56, 133-190. Segalowitz, N., \& Hulstijn, J. (2005). Automaticity in bilingualism and second language learning. (pp. 371-388). New York: Oxford University Press.

Tan, L. H., Spinks, J. A., Feng, C. M., Siok, W. T., Perfetti, C. A., Xiong, J. H., et al. (2003). Neural systems of second language reading are shaped by native language. Human Brain Mapping, 18, 158-166.

Tatsuno, Y., \& Sakai, K. L. (2005). Language-related activations in the left prefrontal regions are differentially modulated by age, proficiency, and task demands. Journal of Neuroscience, 25, 1637-1644.

Urbanik, A., Binder, M., Sobiecka, B., \& Kozub, J. (2001). FMRI study of sentence generation by early bilinguals differing in proficiency level. Rivista di Neuroradiologia, 14, 11-16. 
Bilingual Effect on the Focus and Attention of

Children under Eight

Faizah Saleh AlHammadi

Department of English Language - College of Arts

King Faisal University - Saudi Arabia

\section{Abstract}

Bilingualism is a phenomenon that has significantly spread out in recent times for certain reasons like immigration, marriage of different nationalities, or residence for study abroad, and due to the fact that several Arab families are nowadays keen on sending their children to international schools in which they can acquire a second language, which is often English, besides their native language or mother tongue starting from the age of four years old. These practices resulted in the emergence of new generations of bilingual children who represent the target of the present study so as to detect the differences in their attention and concentration between them and other children who deal in one language with a special emphasis on linking between dealing bilingually and the child's ability to use vocabulary of each language respectively in the right situation and to concentrate on dealing with the specificity of each language separately.

The present study has been applied to children under the age of 8 who deal both in Arabic and English. The researcher 
was keen on the diversity of her study sample in terms of gender (male/female) as well as the diversity of children's age and location. Also, the researcher was keen on focusing on a phenomenon with a special emphasis on attention and concentration as a basis to mental and cognitive processes, a foundation for learning process and a pillar for self-adjustment. The present study adopted experimental method using appropriate statistical tools analyzing data and then processing them statistically. The study revealed that there is a high ability of attention and concentration among bilingual children compared to their monolingual colleagues. Therefore, the study recommended educators to diffuse the importance of bilingualism and to make available kindergartens as well as elementary schools that offer this service in coincidence with encouraging studies that focus on the development of mechanisms of concentration and perception as well as attention in this important age group.

Keywords: Attention, Bilingual, Cognitive Processes 
تأثير ثنائية اللغة على قوى الأطفال المعرفية دون الثامنة

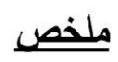

تُعد ظاهرة ثُنائية اللغة من الظواهر التي انتشرت بصورة كبيرة في الآونة الأخيزة لاواعي الهجرة أو الزواج من جنسيات مختلفة ، أو للإقامة للدراسة بالخارج ،وكذلك لحرص الكثير من الأسر العربية في وقتنا الحالي على الحاق ابنائهم بمدارس دولية تكسب الطفل لغة ثانية غالبا ما تكون الانجليزية بجانب لغته الأم من عمر الأربع سنوات ،لقد تجلت هذه الممارسات في ظهور أجيال من الأطفال ثنائي اللغة وهم المستهدفون من الدراسة الحالية وذلك للكثف عن القروق في التركيز والانتباه بينهم وبين الأطفال الآخرين الذين يتعاملون بلغة واحدة مع التركيز على الربط بين التعامل مع لغتين ، وقدرة الطفل على استخدام مفردات كل لغة في الموقف المناسب والتركيز في التعامل مع خصوصية كل لغة. لقد اعتمد البحث الحالي المنهج التجريبي ومن ثم استعمال الوسائل الإحصائية المناسبة لتحليل البيانات ومعالجتها إحصائيا وقد أثبتت الدراسة قدرة عالية على الانتباه والتركيز لدى الأطفال ثنائي اللغة دقارنة بزملائهم أحادي اللغة ولذا فقد أوصت الدراسة التربوين بنشر أهمية ثنائية اللغة واتاحة الروضات والمدارس الابتدائية التي تقدم هذه الخدمة تزامنا مع تشجيع تتديم الاراسات التي تركز على اليات تنمية التركيز والادراك والانتباه في هذه المرحلة العمرية الهامة. 